\title{
Use of pleopod morphology to determine sexual dimorphism and maturity in hermit crabs: Isocheles sawayai as a model
}

\author{
Marina Zilio Fantucci $\cdot$ Renata Biagi • \\ Fernando Luis Mantelatto
}

Received: 25 June 2008 / Revised: 17 December 2008 / Accepted: 9 January 2009 / Published online: 3 February 2009

(C) Springer-Verlag and AWI 2009

\begin{abstract}
In the Anomura, studies on growth patterns are infrequent, possibly because the heterogeneity of the group, especially in terms of morphology, makes it difficult to construct generalized growth models. Particularly hermit crabs are an interesting group to evaluate aspects of growth, because of their unique body. Isocheles sawayai, a hermit crab found only in the western Atlantic Ocean, poorly known with respect to its sexual dimorphism and maturity, was investigated here based on morphometry. Monthly collections (July 2001 through June 2003) were made from a shrimp fishing boat in the Caraguatatuba region on the northern coast of the state of São Paulo, Brazil. The specimens were measured and weighed, and had their sex checked. Throughout the sampling period, 374 specimens of I. sawayai were collected $(11.23 \%$ nonovigerous females, $6.69 \%$ ovigerous females, $79.41 \%$ males and $2.67 \%$ intersexes). The size at which morphological sexual maturity was reached by both sexes ranged from 4.0 to $4.3 \mathrm{~mm}$ shield length, according to the relative growth and the size of the smallest ovigerous female. Sexual dimor-
\end{abstract}

Communicated by H.-D. Franke.

M. Z. Fantucci · R. Biagi · F. L. Mantelatto $(\square)$

Laboratory of Bioecology and Crustacean Systematics,

Department of Biology, Faculty of Philosophy,

Science and Letters of Ribeirão Preto (FFCLRP),

University of São Paulo (USP), Av. Bandeirantes 3900,

Ribeirão Preto, SP CEP 14040-901, Brazil

e-mail: flmantel@usp.br

M. Z. Fantucci - F. L. Mantelatto

Program of Post-Graduation on Comparative Biology,

Faculty of Philosophy,

Science and Letters of Ribeirão Preto (FFCLRP),

University of São Paulo (USP), Ribeirão Preto, SP, Brazil phism was shown by males, which were significantly larger than females, and by differences in growth pattern between the sexes, especially for relationships that involved the pleopods, which is related to their different functions in males and females. The present study is one of the first to use pleopod morphometry to determine sexual maturity and dimorphism in hermit crabs, especially for species with intersexuality such as I. sawayai.

Keywords Anomura $\cdot$ Diogenidae $\cdot$ Relative growth

\section{Introduction}

In spite of the undisputed importance and prominence of the Anomura in the evolutionary context (Cunningham et al. 1992) and the large number of described species, relatively little research has been done on hermit crabs, particularly with respect to sexual maturity and dimorphism; this may be attributed to their lack of commercial value. Studies on the growth patterns of anomurans are even less frequent, possibly because of the heterogeneity of the group, which makes it difficult to construct generalized growth models (Hartnoll 1985). However, studies undertaken during the last two decades have revealed important features of growth in different families and/or genera (Biagi and Mantelatto 2006), signaling and encouraging the continuity of such investigations. Studies of relative growth provide important information on the establishment of morphological sexual maturity and sexual dimorphism, and also supply useful information for systematics (Wenner et al. 1974; Mantelatto and Martinelli 2001).

Some investigators have used the size of the smallest ovigerous female to determine the size at which the population reaches morphological sexual maturity (Bertini and 
Fransozo 1999, 2000; Fransozo et al. 2003). However, environmental changes and genetic factors can cause great variability in a population, and bring about changes in metabolism, growth, reproduction and behavior (Sastry 1983). Considering this potential variability, if possible other features should be used to help establish the size interval at which the puberty molt occurs.

In many species, there are significant differences in behavior and metabolism between males and females, or in the size, shape and growth of individuals or organs, which is termed sexual dimorphism. These between-sex differences can be related to behavior patterns, and are greater when the sexes do not play equal ecological roles (Hartnoll 1974). Such differences are potentially important, both in determining the nature of population regulation within a species, and in determining the nature of interactions between species (Abrams 1988). Sexual dimorphism has been extensively reported for many hermit crabs; almost all studies have focused on the propodus chelipeds and/or these appendages in relation to resource use (Fotheringham 1976; Bertness 1980; Abrams 1988; Manjón-Cabeza and García Raso 1996; Gherardi and Nardone 1997; Fransozo and Mantelatto 1998; Mantelatto and Sousa 2000; Garcia and Mantelatto 2001; Branco et al. 2002; Martinelli et al. 2002; Litulo 2005; Mantelatto et al. 2005). Recently, we demonstrated that the pleopods may be an important aspect to be considered in such studies (Biagi and Mantelatto 2006).

Isocheles sawayai Forest and Saint-Laurent 1968, endemic to the western Atlantic, is the only species of the five members of the genus that is widely distributed along the Brazilian coast, and was also recently reported from Venezuela (Nucci and Melo 2000; Galindo et al. 2008). Recent efforts to improve knowledge of the hermit crabs of Brazilian waters have revealed important and relevant aspects of $I$. sawayai in terms of biogeography, systematics (Mantelatto et al. 2006), biology and reproduction (Fantucci et al. 2007, 2008; Mantelatto et al. 2009), such as intersexuality. We used this species as a model to evaluate morphological parameters as instruments to establish the size at which sexual maturity occurs, and to evaluate the presence of sexual dimorphism.

\section{Methods}

The hermit crabs were collected monthly from July 2001 through June 2003, in the Caraguatatuba region $\left(23^{\circ} 36^{\prime} 08^{\prime \prime}-23^{\circ} 47^{\prime} 07^{\prime \prime} \mathrm{S} ; 45^{\circ} 20^{\prime} 03^{\prime \prime}-45^{\circ} 08^{\prime} 30^{\prime \prime} \mathrm{W}\right)$, southern coast of São Paulo, Brazil, from a fishing boat equipped with two double-rig trawl nets (20-mm mesh size in the net body and $15 \mathrm{~mm}$ in the cod end). The region is sheltered against the direct action of ocean waves by São Sebastião
Island (Ilhabela), and is influenced by the São Sebastião Channel, resulting in moderate hydrodynamics and homogeneous morphology of the bottom (Barros et al. 1997). The region is influenced by three different water masses, the South Atlantic Central Water (SACW) with low temperature and salinity, Tropical Water (TW) with high temperature and salinity, and Coastal Water (CW) with high temperature and low salinity, in different periods of the year (Castro-Filho et al. 1987). Each trawl was made parallel to the coast, at 5-m depth (Fantucci et al., in preparation), and lasted approximately $30 \mathrm{~min}$, at a mean speed of two knots.

After collection, the specimens were sorted, frozen, and transported to the laboratory. There, they were removed from their shells, counted, and weighed (wet weight, WW) $(0.01 \mathrm{~g})$, and the sex was checked according to the gonopore position and pleopod morphology. For the evaluation of sexual dimorphism, intersexes were grouped with males because the analysis of external primary (gonopores) and secondary (pleopods) sexual characters revealed a greater similarity between males and intersexes, than between intersexes and females, suggesting that intersex individuals are functional males (Fantucci et al. 2007).

Individuals were measured for cephalothoracic shield length and width (SL and SW) and left cheliped propodus length and width (CPL and CPW), using a caliper $(0.01 \mathrm{~mm})$. As described by Biagi and Mantelatto (2006), the second pleopod protopod, endopod and exopod length (PPL, EPL and XPL) were measured by means of a stereomicroscope equipped with a camera lucida. Hermit crabs with damaged or absent appendages were excluded from analyses of relationships that involved the dimensions of these appendages.

Sizes of males and females were compared by Student's $t$ test for parametric values and by Mann-Whitney for non-parametric ones, to check sexual dimorphism. The relationships between size and weight were analyzed by regression and dispersion diagrams of the empirical points, using the power function $y=a x^{b}$ (Zar 1996), and linear equation $(\ln y=\ln a+\operatorname{bln} x)$ ( $y \mathrm{SW}, \mathrm{CPL}, \mathrm{CPW}$, WW, PPL, EPL, XPL; $\times$ SL; $a$ intercept; $b$ slope). Departures from isometry $\left(\mathrm{H}_{0}, b=1 ; \mathrm{H}_{1}, b \neq 1\right.$ for size dimensions, and $\mathrm{H}_{0}, b=3 ; \mathrm{H}_{1}, b \neq 3$ for weight) (Huxley and Teissier 1936; Hartnoll 1982; Biagi and Mantelatto 2006) were tested using the Student's $t$ test on the slope values obtained (Zar 1996).

Data were analyzed statistically at the level of significance $P<0.05$ (Zar 1996), and by the program Sigma Stat for Windows, Version 2.03. Voucher specimens were deposited in the Crustacean Collection of the Department of Biology, Faculty of Philosophy, Science and Letters of Ribeirão Preto (FFCLRP), University of São Paulo (USP), Brazil (CCDB/FFCLRP/USP, accession numbers 16871691). 


\section{Results}

During the sampling period, 374 specimens of I. sawayai were collected: 297 males (79.41\%), 42 nonovigerous females (11.23\%), 25 ovigerous females $(6.69 \%)$ and 10 intersexes $(2.67 \%)$. The smallest and the largest individuals were both males, and measured 3.4 and $9.8 \mathrm{~mm}$ SL. The smallest ovigerous female measured $4.3 \mathrm{~mm} \mathrm{SL}$ (Table 1).
A clear break in the growth pattern of CPL and XPL occurred, for both sexes, between 4.0 and $4.3 \mathrm{~mm} \mathrm{SL}$ (Fig. 1). Thus, morphological sexual maturity was estimated for the interval from 4.0 to $4.3 \mathrm{~mm}$ SL. Few recruits or juveniles (smaller than this estimated size interval) were collected (four males and two females only).

This population of I. sawayai showed pronounced sexual dimorphism. Males were significantly larger than females $(P<0.05)$, except for the pleopods (Table 1). Sexes

Table 1 Isocheles sawayai: dimensions for each group of interest

\begin{tabular}{|c|c|c|c|c|c|c|c|}
\hline Dimensions & $N$ & Sex & Minimum & Maximum & $\mathrm{x} \pm \mathrm{SD}$ & $T$ & $P$ \\
\hline \multirow[t]{2}{*}{ SL } & 307 & M & 3.4 & 9.8 & $7.0 \pm 1.2$ & \multirow[t]{2}{*}{$5,752.0$} & \multirow[t]{2}{*}{$\leq 0.001$} \\
\hline & 67 & $\mathrm{~F}$ & 3.8 & 8.0 & $5.6 \pm 0.9$ & & \\
\hline \multirow[t]{2}{*}{ SW } & 307 & M & 3.4 & 10.5 & $7.4 \pm 1.2$ & \multirow[t]{2}{*}{$-9.218 *$} & \multirow[t]{2}{*}{$\leq 0.001$} \\
\hline & 67 & $\mathrm{~F}$ & 4.1 & 8.4 & $6.0 \pm 0.9$ & & \\
\hline \multirow[t]{2}{*}{ CPL } & 306 & M & 4.3 & 12.3 & $8.8 \pm 1.5$ & \multirow[t]{2}{*}{$4,223.0$} & \multirow[t]{2}{*}{$\leq 0.001$} \\
\hline & 66 & F & 5.1 & 9.0 & $6.5 \pm 0.8$ & & \\
\hline \multirow[t]{2}{*}{ CPW } & 306 & M & 2.9 & 8.4 & $5.9 \pm 1.0$ & \multirow[t]{2}{*}{$5,434.0$} & \multirow[t]{2}{*}{$\leq 0.001$} \\
\hline & 66 & F & 3.3 & 6.4 & $4.7 \pm 0.7$ & & \\
\hline \multirow[t]{2}{*}{ WW } & 307 & M & 0.30 & 10.53 & $3.55 \pm 1.84$ & \multirow[t]{2}{*}{$4,624.0$} & \multirow[t]{2}{*}{$\leq 0.001$} \\
\hline & 67 & $\mathrm{~F}$ & 0.39 & 4.19 & $1.42 \pm 0.67$ & & \\
\hline \multirow[t]{2}{*}{ PPL } & 305 & M & 0.5 & 3.3 & $1.6 \pm 0.4$ & \multirow[t]{2}{*}{$14,952.0$} & \multirow[t]{2}{*}{0.002} \\
\hline & 66 & F & 0.7 & 3.7 & $1.9 \pm 0.6$ & & \\
\hline \multirow[t]{2}{*}{ EPL } & 305 & M & 2.1 & 9.6 & $5.4 \pm 1.3$ & \multirow[t]{2}{*}{$10,738.5$} & \multirow[t]{2}{*}{0.028} \\
\hline & 66 & $\mathrm{~F}$ & 2.4 & 8.2 & $4.9 \pm 1.4$ & & \\
\hline \multirow[t]{2}{*}{ XPL } & 266 & M & 0.3 & 2.7 & $0.8 \pm 0.3$ & \multirow[t]{2}{*}{$19,869.0$} & \multirow[t]{2}{*}{$\leq 0.001$} \\
\hline & 66 & F & 1.1 & 5.5 & $2.9 \pm 0.9$ & & \\
\hline
\end{tabular}

$M$ males, $F$ females, $S L$ cephalothoracic shield length $(\mathrm{mm}), S W$ cephalothoracic shield width $(\mathrm{mm}), C P L$ left cheliped propodus length (mm), $C P W$ left cheliped propodus width $(\mathrm{mm}), W W$ hermit crab wet weight $(\mathrm{g}), P P L$ second pleopod protopod length (mm), EPL second pleopod endopod length (mm), $X P L$ second pleopod exopod length $(\mathrm{mm}), N$ number of individuals, $x$ mean, $S D$ standard deviation, $T$ Mann-Whitney value

* $t$ test value
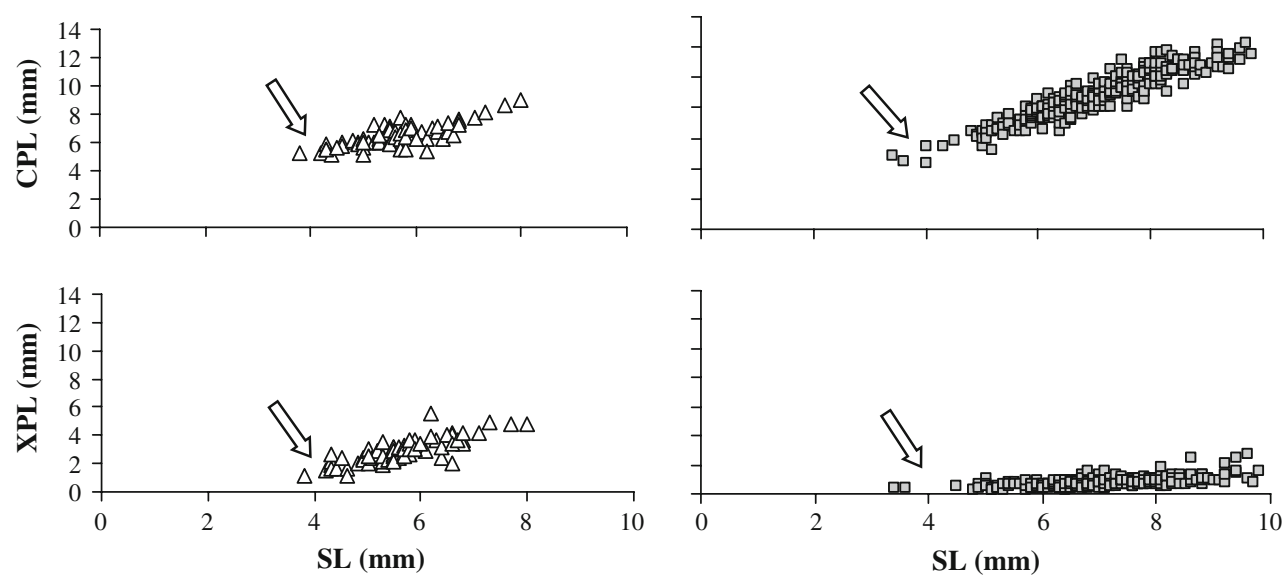

$\triangle$ Females $\square$ Males

Fig. 1 Isocheles sawayai. Relative growth of left cheliped propodus length (CPL) and second pleopod exopod length (XPL) in relation to cephalothoracic shield length (SL). Arrows indicate the interval at which the discontinuity of points suggests the size at which sexual maturity occurs 

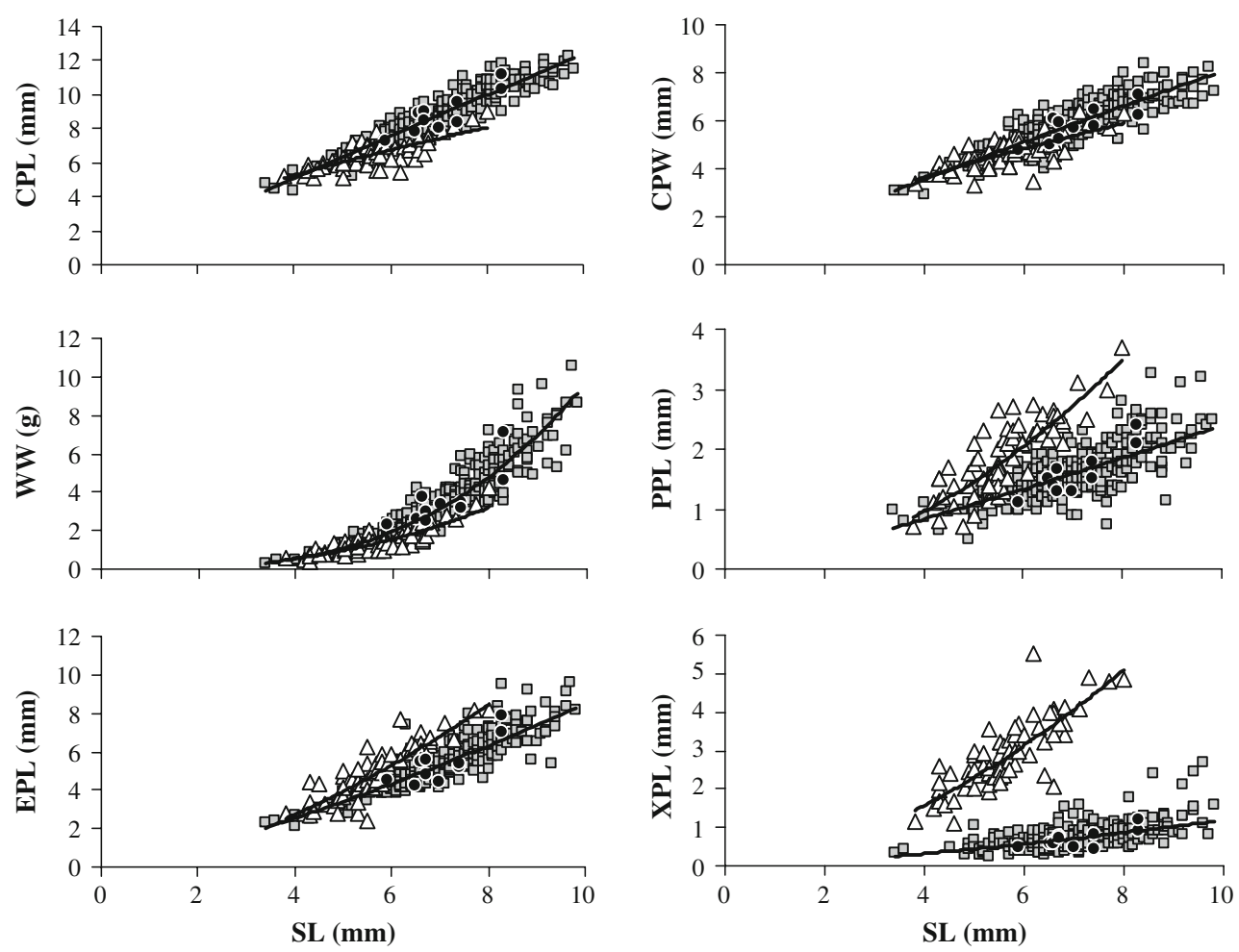

口 Males $\triangle$ Females $\bullet$ Intersexes

Fig. 2 Isocheles sawayai. Diagrams of dispersion of empirical points for relationships that showed sexual dimorphism: $S L$ cephalothoracic shield length, $C P L$ left cheliped propodus length, $C P W$ left cheliped

differed in growth patterns, which was best evidenced by relationships that involved the left cheliped propodus length (CPL), weight (WW) and the second pleopod (PPL, EPL and XPL) (Fig. 2; Table 2).

Regarding the intersex individuals, the relationships of pleopod morphometry corroborated the decision to group them with the males (Fig. 2).

\section{Discussion}

Sexual dimorphism was evidenced by differences in growth pattern between sexes, especially for relationships that involved the pleopods, which is related to the different function of these appendages between the sexes. The present study is one of the first to use pleopod morphometry to determine sexual maturity and dimorphism in hermit crabs, especially for species with intersexuality such as I. sawayai.

When morphometric parameters are utilized to describe growth in crustaceans, it is important to analyze these parameters in individuals of different sizes in order to distinguish adults and juveniles (Hartnoll 1982). However, studies on hermit crabs have demonstrated that juveniles may not be common in samples, as reported for Paguristes propodus width, $W W$ hermit crab weight, $P P L$ second pleopod protopod length, $E P L$ second pleopod endopod length, $X P L$ second pleopod exopod length

tortugae Schmitt, 1933, Pagurus brevidactylus (Stimpson, 1859), Dardanus deformis (H. Milne-Edwards, 1836) and Pagurus exilis (Benedict, 1892) (Mantelatto and Sousa 2000; Mantelatto et al. 2005; Litulo 2005; Mantelatto et al. 2007, respectively), even in studies conducted for several months, as the present study. Collection of small numbers of juveniles could be a consequence of sampling failure, or could reflect the existence of different spatial distributions in juveniles and adults. Different distributions may be related to juvenile migration, because hermit crabs migrate looking for better food supplies, shells of adequate size, and protection against predators (Fotheringham 1975).

Although the absence or the low number of juveniles in collections may not allow the adults and juveniles' growth patterns and their differences to be estimated, other indicators can be used to characterize the transition between the juvenile and adult phases. According to Hartnoll (1982), the morphological and physiological maturity may not be in synchrony. However, in the population studied here, the estimated size for morphological maturity in the relative growth (dispersion of empirical points) was corroborated by the size of the smallest ovigerous female found.

Isocheles sawayai showed sexual dimorphism in size, as do the majority of hermit crab species that have been 
Table 2 Isocheles sawayai: regression equations for each sex

\begin{tabular}{|c|c|c|c|c|c|c|c|}
\hline Relationship & $N$ & Sex & Power function $y=a x^{b}$ & Linear equation $\ln y=\ln a+b \ln x$ & $r$ & $\mathrm{~A}$ & $b \neq 1$ \\
\hline \multirow[t]{2}{*}{$\mathrm{SL} \times \mathrm{SW}$} & 307 & M & $\mathrm{SW}=1.220 \mathrm{SL}^{0.924}$ & $\operatorname{lnSW}=0.199+0.924 \operatorname{lnSL}$ & 0.951 & - & $4.42 *$ \\
\hline & 67 & $\mathrm{~F}$ & $\mathrm{SW}=1.2587 \mathrm{SL}^{0.900}$ & $\operatorname{lnSW}=0.230+0.900 \operatorname{lnSL}$ & 0.928 & - & $2.23 *$ \\
\hline \multirow[t]{2}{*}{$\mathrm{SL} \times \mathrm{CPL}$} & 306 & M & $\mathrm{CPL}=1.286 \mathrm{SL}^{0.985}$ & $\operatorname{lnCPL}=0.252+0.985 \operatorname{lnSL}$ & 0.935 & $=$ & 0.701 \\
\hline & 66 & $\mathrm{~F}$ & $\mathrm{CPL}=2.234 \mathrm{SL}^{0.617}$ & $\operatorname{lnCPL}=0.804+0.617 \operatorname{lnSL}$ & 0.760 & - & $5.08 *$ \\
\hline \multirow[t]{2}{*}{$\mathrm{SL} \times \mathrm{CPW}$} & 306 & $\mathrm{M}$ & $\mathrm{CPW}=1.022 \mathrm{SL}^{0.898}$ & $\operatorname{lnCPW}=0.0219+0.898 \operatorname{lnSL}$ & 0.881 & - & $3.70^{*}$ \\
\hline & 66 & $\mathrm{~F}$ & $\mathrm{CPW}=1.414 \mathrm{SL}^{0.687}$ & $\operatorname{lnCPW}=0.347+0.687 \operatorname{lnSL}$ & 0.749 & - & $4.12 *$ \\
\hline \multirow[t]{2}{*}{$\mathrm{SL} \times \mathrm{WW}$} & 307 & M & $\mathrm{WW}=0.007 \mathrm{SL}^{3.148}$ & $\operatorname{lnWW}=-4.971+3.148 \operatorname{lnSL}$ & 0.946 & + & $2.39^{\mathrm{a}}$ \\
\hline & 67 & $\mathrm{~F}$ & $\mathrm{WW}=0.016 \mathrm{SL}^{2.547}$ & $\operatorname{lnWW}=-4.123+2.547 \mathrm{lnSL}$ & 0.864 & - & $2.46^{\mathrm{a}}$ \\
\hline \multirow[t]{2}{*}{$\mathrm{SL} \times \mathrm{PPL}$} & 305 & M & $\mathrm{PPL}=0.165 \mathrm{SL}^{1.163}$ & $\ln P P L=-1.801+1.163 \ln S L$ & 0.731 & + & $2.62 *$ \\
\hline & 66 & $\mathrm{~F}$ & $\mathrm{PPL}=0.072 \mathrm{SL}^{1.863}$ & $\operatorname{lnPPL}=-2.626+1.863 \operatorname{lnSL}$ & 0.801 & + & $4.96^{*}$ \\
\hline \multirow[t]{2}{*}{$\mathrm{SL} \times \mathrm{EPL}$} & 305 & M & $\mathrm{EPL}=0.410 \mathrm{SL}^{1.314}$ & $\operatorname{lnEPL}=-0.891+1.314 \operatorname{lnSL}$ & 0.903 & + & $8.72 *$ \\
\hline & 66 & $\mathrm{~F}$ & $\mathrm{EPL}=0.289 \mathrm{SL}^{1.623}$ & $\operatorname{lnEPL}=-1.242+1.623 \ln \mathrm{nL}$ & 0.845 & + & $4.83^{*}$ \\
\hline \multirow[t]{2}{*}{$\mathrm{SL} \times \mathrm{XPL}$} & 266 & M & $\mathrm{XPL}=0.0456 \mathrm{SL}^{1.412}$ & $\operatorname{lnXPL}=-3.139+1.438 \operatorname{lnSL}$ & 0.623 & + & $3.95 *$ \\
\hline & 66 & $\mathrm{~F}$ & $\mathrm{XPL}=0.151 \mathrm{SL}^{1.693}$ & $\operatorname{lnXPL}=-1.891+1.693 \ln \mathrm{SL}$ & 0.807 & + & $4.47 *$ \\
\hline
\end{tabular}

$M$ males, $F$ females, $S L$ cephalothoracic shield length $(\mathrm{mm}), S W$ cephalothoracic shield width $(\mathrm{mm}), C P L$ left cheliped propodus length (mm), $C P W$ left cheliped propodus width $(\mathrm{mm}), W W$ hermit crab wet weight $(\mathrm{g}), P P L$ second pleopod protopod length (mm), $E P L$ second pleopod endopod length (mm), XPL second pleopod exopod length $(\mathrm{mm}), N$ number of individuals, $r$ correlation coefficient, $A$ allometry

* Significant correlation, $P<0.05$

a $b \neq 3$

studied. The larger size attained by males has been attributed to differential energy consumption, because as males do not produce eggs they can channel their energy into somatic growth. Being larger may also be advantageous because it influences sexual selection, with larger males being more successful in fights for mating pairs, causes a differential shell occupation pattern between sexes, reducing competition for adequate shells, and causes different food-supply use and risk of death, in case of differential habitat occupation between sexes (Abrams 1988).

This population of I. sawayai was also sexually dimorphic in relative growth. The chelar propodi of males and females grew at different rates. This may be attributed to the males using this appendage in territorial defense, intraand inter-specific fights, the shell selection process, and also in mating behavior (Hazlett 1966), explaining the adaptive significance of the larger chelae in males. Males not only grew more, but also showed different rates of weight gain than did females (positive allometry vs. negative allometry, respectively). This can be explained by the females diverting energy from somatic growth, and channeling it into egg production and care (Bertness 1981; Abrams 1988; Mantelatto and Martinelli 2001; Fransozo et al. 2003).

The pleopods of hermit crabs were shown to be important features that must be investigated in relative growth studies, because of their known changes throughout development and functionality in reproduction (Biagi and
Mantelatto 2006). However, this aspect has been little studied in hermit crabs.

Members of the genus Isocheles have unpaired biramous pleopods on the second to fifth abdominal somites (Forest and Saint-Laurent 1968). These pleopods have different morphologies and functions in each sex. Therefore, the growth pattern of these structures is very useful for determining sexual dimorphism. The pleopods of female decapod crustaceans are robust and setose, which allows the eggs to adhere to them (Ingle 1993). As shown for Paguristes erythrops Holthuis, 1959 (Biagi and Mantelatto 2006), the female pleopods of $I$. sawayai grew more (positive allometry for all relationships) than those of the males; this can be explained by their reproductive function in mature females, because in males, these structures function only to move the water inside the shell, contributing to cleaning and aeration.

In addition to demonstrating the importance of using other morphometric parameters to determine sexual dimorphism and sexual maturity, the present study corroborated the use of pleopods as an important tool to identify the sex, especially in species of hermit crabs with intersex individuals, such as I. sawayai. Furthermore, although relative growth is considered a trustworthy tool to determine size at sexual maturity, mainly for hermit crab species with clear chelipedal dimorphism, such as the diogenids (Fransozo et al. 2003), the present study showed that there are other features, such as the pleopods, that allow this kind of analysis. 
Acknowledgments This study was part of the BSc thesis of M.Z.F., and was supported by a Scientific Initiation Fellowship from PIBIC/ CNPq. R.B. and F.L.M. are grateful to $\mathrm{CNPq}$ for postdoctoral and research fellowships. Special thanks are due to Dr. Adilson Fransozo (UNESP) for support and facilities during sampling collections provided by the FAPESP-Biota Program (Proc. 98/070900-3), to all our NEBECC colleagues, and to Andrea L. Meireles (Laboratory of Bioecology and Crustacean Systematics-LBSC/FFCLRP/USP) for their help during field and laboratory work. The support of the Postgraduate Program in Comparative Biology of FFCLRP/USP and the Centro de Biologia Marinha (CEBIMar/USP) during field work is gratefully acknowledged. We also thank the anonymous reviewers for their suggestions and contributions toward the improvement of this paper. Dr. Janet W. Reid revised the English text. All experiments conducted in this study comply with current applicable state and federal laws.

\section{References}

Abrams PA (1988) Sexual difference in resource use in hermit crabs: consequences and causes. In: Chelazzi G, Vannini M (eds) Behavioral adaptations to intertidal life. Plenum, New York, pp 283-296

Barros CE, Corrêa ICS, Baitelli R, Elias ARD (1997) Aspectos sedimentares da Enseada de Caraguatatuba, litoral do estado de São Paulo. An Acad Bras Cienc 69:19-36

Bertini G, Fransozo A (1999) Relative growth of Petrochirus diogenes (Linnaeus, 1758) (Crustacea, Anomura, Diogenidae) in the Ubatuba region, São Paulo, Brazil. Rev Brasil Biol 59:617-625

Bertini G, Fransozo A (2000) Population dynamics of Petrochirus diogenes (Crustacea, Anomura, Diogenidae) in the Ubatuba region, São Paulo, Brazil. Crustac Issues 12:331-342

Bertness MD (1980) Shell preference and utilization patterns in littoral hermit crabs of the Bay of Panama. J Exp Mar Biol Ecol 48:1-16

Bertness MD (1981) Pattern and plasticity in tropical hermit crab growth and reproduction. Am Nat 117:754-773

Biagi R, Mantelatto FL (2006) Relative growth and sexual maturity of the hermit crab Paguristes erythrops (Anomura, Diogenidae) from South Atlantic. Hydrobiologia 559:247-254

Branco JO, Turra A, Souto FX (2002) Population biology and growth of the hermit crab Dardanus insignis at Armação do Itapocoroy, southern Brazil. J Mar Biol Ass UK 82:597-603

Castro-Filho BM, Miranda LB, Miyao SY (1987) Condições hidrográficas na plataforma continental ao largo de Ubatuba: variações sazonais e em média escala. Bol Inst Oceanogr 35:135151

Cunningham CW, Blackstone NW, Buss LW (1992) Evolution of king crabs from hermit crab ancestors. Nature 355:539-542

Fantucci MZ, Biagi R, Mantelatto FL (2007) Record of intersexuality in the western Atlantic hermit crab Isocheles sawayai (Anomura, Diogenidae). J Mar Biol Ass UK-Biodiversity Records. http:// www.mba.ac.uk/jmba/pdf/5735.pdf

Fantucci MZ, Biagi R, Mantelatto FL (2008) Shell occupation by the endemic western Atlantic hermit crab Isocheles sawayai (Diogenidae) from Caraguatatuba, Brazil. Braz J Biol 68:859-867

Forest J, Saint-Laurent M (1968) Campagne de la Calypso au large de côtes atlantiques de 1'Amérique du Sud (1961-1962). 6. Crustacés Decápodes: Pagurides. Ann Inst Oceanogr 45:47-169

Fotheringham N (1975) Structure of seasonal migrations of the littoral hermit crab Clibanarius vittatus (Bosc). J Exp Mar Biol Ecol 18:47-53

Fotheringham N (1976) Population consequences of shell utilization by hermit crabs. Ecology 57:570-578

Fransozo A, Mantelatto FL (1998) Population structure and reproductive period of the tropical hermit crab Calcinus tibicen
(Decapoda: Diogenidae) in the region of Ubatuba, São Paulo, Brazil. J Crust Biol 18:738-745

Fransozo A, Garcia RB, Mantelatto FL (2003) Morphometry and sexual maturity of the tropical hermit crab Calcinus tibicen (Crustacea, Anomura) from Brazil. J Nat Hist 37:297-304

Galindo LA, Bolaños JA, Mantelatto FL (2008) Shell utilization pattern by the hermit crab Isocheles sawayai Forest and Saint Laurent, 1968 (Anomura, Diogenidae) from Margarita Island, Caribbean Sea, Venezuela. Gulf Caribb Res 20:49-57

Garcia RB, Mantelatto FL (2001) Population dynamics of the hermit crab Paguristes erythrops (Diogenidae) from Anchieta Island, southern Brazil. J Mar Biol Ass UK 81:955-960

Gherardi F, Nardone F (1997) The question of coexistence in hermit crab: population ecology of a tropical intertidal assemblage. Crustaceana 70:608-629

Hartnoll RG (1974) Variation in growth pattern between some secondary sexual characters in crab (Decapoda Brachyura). Crustaceana $27: 131-136$

Hartnoll RG (1982) Growth. In: Abele LG (ed) The biology of Crustacea-embryology, morphology and genetics. Academic, New York, pp 111-196

Hartnoll RG (1985) Growth, sexual maturity and reproductive output. In: Wenner AM (ed) Factors in adult growth. AA Balkema, Rotterdam, pp 101-128

Hazlett BA (1966) Social behavior of the Paguridae and Diogenidae of Curaçao. Stud Fauna Curaçao 23:1-143

Huxley JS, Teissier G (1936) Terminology of relative growth. Nature 137:780-781

Ingle R (1993) The hermit crabs of the northeastern Atlantic Ocean and Mediterranean Sea-an illustrated key. Chapman and Hall, London

Litulo C (2005) Population structure and reproduction of the hermit crab Dardanus deformis (Anomura: Diogenidae) in the Indian Ocean. J Mar Biol Ass UK 85:883-887

Manjón-Cabeza ME, García Raso JE (1996) Study of the size relationships and relative growth of Cestopagurus timidus (Roux). A method for separating groups (Crustacea, Decapoda, Anomura). Spixiana 19:239-248

Mantelatto FL, Martinelli JM (2001) Relative growth and sexual dimorphism of the South Atlantic hermit crab Loxopagurus loxochelis (Anomura, Diogenidae) from Ubatuba, Brazil. J Nat Hist 35:429-437

Mantelatto FL, Sousa LM (2000) Population biology of the hermit crab Paguristes tortugae Schmitt, 1933 (Anomura, Diogenidae) from Anchieta Island, Ubatuba, Brazil. Nauplius 8:185-193

Mantelatto FL, Christofoletti RA, Valenti WC (2005) Population structure and growth of the hermit crab Pagurus brevidactylus (Anomura: Paguridae) from the northern coast of São Paulo, Brazil. J Mar Biol Ass UK 85:127-128

Mantelatto FL, Robles R, Biagi R, Felder DL (2006) Molecular analysis of the taxonomic and distributional status for the hermit crab genera Loxopagurus Forest, 1964, and Isocheles Stimpson, 1858 (Decapoda, Anomura, Diogenidae). Zoosystema 28:495-506

Mantelatto FL, Espósito DLA, Terossi M, Biagi R, Meireles AL (2007) Population features of the Western Atlantic hermit crab Pagurus exilis (Anomura, Paguridae) in Brazil. Atlântica 29:107114

Mantelatto FL, Scelzo MA, Tudge CC (2009) Morphological and morphometric appraisal of the spermatophore of the southern hermit crab Isocheles sawayai Forest and Saint-Laurent, 1968 (Anomura: Diogenidae), with comments on gonopores in both sexes. Zool Anzeig. doi:10.1016/j.jcz.2008.06.002

Martinelli JM, Mantelatto FL, Fransozo A (2002) Population structure and breeding season of the South Atlantic hermit crab, Loxopagurus loxochelis (Anomura, Diogenidae) from the Ubatuba region, Brazil. Crustaceana 75:791-802 
Nucci PR, Melo GAS (2000) Range extensions for eight species of western Atlantic hermit crabs (Crustacea, Paguroidea). Nauplius $8: 141-147$

Sastry AN (1983) Ecological aspects of reproduction. In: Vernberg FJ, Vernberg WB (eds) The biology of crustacea-environmental adaptations. Academic, New York, pp 179-270
Wenner AM, Fussaro C, Oaten A (1974) Size at onset of sexual maturity and growth rate in crustacean populations. Can J Zool 52:1095-1106

Zar JH (1996) Biostatistical analysis. Prentice-Hall, New Jersey 